\title{
Implikasi Itsbat Nikah Tehadap Status Perkawinan Dan Anak Dalam Kepastian Hukum
}

\author{
T o i f \\ Alumni Program Studi Magister Kenotariatan \\ Pascasarjana Universitas Islam Bandung \\ e-mail: toifali@gmail.com
}

\begin{abstract}
Abstrak-Pernikahan yang dilakukan di hadapan pegawai pencatat nikah perlu dicatatkan untuk mendapatkan konfirmasi pernikahan (Itsbat). Penelitianini mengkaji implikasi itsbat nikah terhadap status perkawinan dan status anaknya dihubungkan dengan asas kepastian hukum dan untuk memahami pertanggungjawaban pegawai pencatat nikah yang tidak mencatat perkawinan. Penelitian ini menggunakan metode yuridis normatif melalui dua pendekatan, yaitu pendekatan perundang-undangan dan pendekatan kasus. Hasil penelitian menunjukkan bahwa itsbat nikah berperan dalam menetapkan keberadaan status perkawinan dihubungkan dengan prinsip kepastian hukum. Oleh karena itu, petugas pencatat nikah yang dengan sengaja tidak mencatatkan pernikahan dianggap telah melakukan tindakan melanggar hukum sebagaimana diatur dalam undang-undang yang berlaku di Indonesia.
\end{abstract}

\section{Kata kunci: Itsbat, Petugas Pendaftaran Pernikahan, Status Perkawinan.}

\begin{abstract}
Marriage carried out in front of the registrar need to be recorded to obtain marriage confirmation (Itsbat). This research examines the provision of Itsbat on marital status and the status of their children in accordance with the principle of legal certainty and its implementation toward the marriage that was not recorded by marriage registrar officer. This research uses normative juridical method through two approaches, namely the statute approach and the case approach. The results of this research showed that the assignment of Itsbat works for the existence of marriage (marital status) which is associated with the principle of legal certainty. Therefore, a marriage registrar officer who intentionally does not record such marriage is deemed to have committed an unlawful act, and subject to sanctions as stipulated in the applicable laws and regulations in Indonesia.
\end{abstract}

Keywords: Itsbat, Marriage Registrar Officer, Marital Status.

\section{A. PENDAHULUAN}

Perkawinan yang dilakukan menurut hukum masing-masing agamanya dan kepercayaannya itu adalah merupakan suatu perkawinan yang sah, hal ini sesuai dengan Pasal 2 ayat (1) Undang-
Undang Nomor 1 Tahun 1974

tentang Perkawinan, sehingga hubungan hukum ini, akan mempunyai implikasi hukum terhadap keabsahan hubungan pasangan suami isteri dan memberikan legitimasi pergaulan 
To i f, Implikasi Itsbat Nikah Tehadap Status Perkawinan Dan Anak Dalam Kepastian Hukum...

laki-laki dan perempuan secara
terhormat, sesuai dengan
kedudukan manusia sebagai
mahluk Tuhan yang sempurna,
yaitu memiliki akal (pikiran) dan
perasaan (hati) dan mendapatkan
perlindungan hukum.

Meskipun perkawinan yang dilakukan sesuai dengan Pasal 2 ayat (1) Undang-Undang Nomor 1 Tahun 1974 tentang Perkawinan, dianggap belum sempurna manakala belum dilengkapi dengan pelaksanaan Pasal 2 ayat (2) Undang-Undang Nomor 1 Tahun 1974 tentang Perkawinan, karena Pasal 2 ayat (1) merupakan norma keteraturan, sedangkan Pasal 2 ayat (2), merupakan norma ketertiban, oleh karenanya, kedua norma tersebut harus digunakan secara bersama-sama, menjadi satu kesatuan yang tidak dipisahpisahkan. Perkawinan yang semacam itulah, yang dapat dikatakan sebagai perbuatan hukum, karena telah dilakukan menurut ketentuan hukum yang berlaku secara positif, sehingga perkawinan tersebut telah memperoleh kepastian hukum dan berhak mendapatkan perlindungan hukum.

Sedangkan perkawinan yang dilakukan hanya sesuai dengan Pasal 2 ayat (1), yang tidak memenuhi norma ketertiban, tentunya belum bisa dikatakan sebagai perkawinan yang mempunyai kepastian hukum, oleh karenanya, perkawinan tersebut berhak mendapatkan perlindungan hukum dalam upaya mendapatkan kepastian hukum.

Berhaknya mendapatkan kepastian hukum, disebabkan perkawinan tersebut dilakukan dibawah pengawasan dan dihadapan pegawai pencatat nikah, namun pegawai pencatat nikah tidak melaksanakan Pasal 2 ayat (2) dari Undang- Undang Perkawinan tentang pencatatan perkawinan. Sedangkan Pencatatan perkawinan, bertujuan untuk mewujudkan ketertiban perkawinan, sehingga perkawinan tersebut, mampu dibuktikan dengan dimilikinya buku kutipan Akta Nikah dan masing-masing suami isteri, mendapat satu buku kutipan akta nikah, sehingga 
dengan buku kutipan akta nikah tersebut, mampu digunakan untuk menuntut hak-hak diantara pasangan suami istri, sekiranya terjadi permasalah dalam ikatan perkawinan.

Buku kutipan akta nikah, sebagai bukti otentik sahnya suatu perkawinan, sangat bermanfaat bagi pasangan suami istri dan anak-anak yang dilahirkan, bukti tersebut sebagai payung hukum bilamana terjadi pengingkaran atas keabsahan perkawinannya dan sebagai dasar untuk menuntut hakhak yang seharusnya diterima, juga untuk melindungi dari fitnah dan qadzaf zina (tuduhan zina), serta sebagai bukti untuk menuntut dan melindungi hak-hak anak yang dilahirkan dari perkawinan tersebut. Maka jelaslah bahwa pencatatan nikah adalah sangat urgen dalam perkawinan.

Dalam Pasal 2 ayat (1), Undang Undang Nomor 1 Tahun 1974 tentang perkawinan, yang menyatakan "Perkawinan adalah sah apabila dilakukan menurut hukum agama dan kepercayaannya itu”. Ketentuan ini merupakan perwujudan dan kompromi kesadaran hukum yang berlainan dari adanya diferensiasi di dalam unifikasi bidang hukum (Abdul Gani Abdullah, 1994:27).

Perlu diperhatikan, dari rumusan Pasal 2 ayat (2), bahwa perkawinan dicatat menurut peraturan perundang-undangan yang berlaku, pada faktanya, berdasarkan perkara permohonan itsbat nikah yang diajukan di Pengadilan Agama Trenggalek, masih ditemukan perkawinan yang dilakukan di hadapan pegawai pencatat nikah namun perkawinan tersebut tidak dicatat, sehingga perkawinan tersebut tidak diakui sebagai perkawinan yang telah memenuhi Pasal 2 ayat (2), Undang-Undang Nomor 1 tahun 1974 tentang Perkawinan, sehingga pasangan suami istri tidak dicatat oleh pegawai pencatat perkawinan, meskipun perkawinan tersebut dilakukan di hadapan dan di bawah pengawasannya, sehingga perkawinan tersebut belum mendapatkan kepastian.

$$
\text { Pengadilan }
$$

Agama Trenggalek juga pernah menerima 
permohonan asal-usul anak yang diajukan oleh pasangan suami istri, dengan alasan, pasangan suami istri tersebut tidak mempunyai Buku Kutipan Akta Nikah, karena tidak diberi oleh pegawai pencatat perkawinan, meskipun perkawinannya telah dilakukan di hadapan dan di bawah pengawsannya.

Dengan tidak dimilikinya kutipan akta nikah, maka pasangan suami isteri, mendapatkan kesulitan-kesulitan di dalam memperoleh hak-haknya dan kesulitan tersebut juga dialami oleh anak-anaknya, seperti halnya kesulitan mengurus Akta Kelahiran dan hak-hak lainya yang berkaitan dengan bukti atas perkawinannya, karena belum mendapatkan kepastian hukum.

Dalam rangka memperoleh kepastian hukum, diperlukan perlindungan hukum terhadap anak-anak yang lahir dari perkawinan yang tidak dicatat oleh pencatat. Negara dan pemerintah, bertanggung jawab atas penyediaan fasilitas dan eksebilitas bagi anak (Andi Syamsu Alam H. dan M. Fauzan H., 2008:1-2), terutama dalam rangka mendapatkan hak-hak dan kewajiban sebagai orang yang dilahirkan dari perkawinan orang tuanya dan perlu mendapatkan perlindangan hukum dalam upaya mendapatkan kepastian hukum atas setatusnya sebagai seorang anak, dengan segala akibat hukum yang bisa diterima sebagai seorang anak yang sah.

Terhadap

pencatat perkawinan yang dengan sengaja tidak mencatat perkawinan yang telah dilakukan di hadapanya, dengan segala konsekwensi hukum, pencatat perkawinan harus mempertanggungjawabkan sesuai dengan administrasi negara.

Berdasarka uraian dari latar belakang diatas, adapun identiikasi masalah dari latar belakang tersebut adalah:

1. Bagaimana implikasi itsbat nikah terhadap status perkawinan dan status anaknya, dihubungkan dengan asas kepastian hukum?

2. Bagaimana pertanggung jawaban hukum, pegawai 
T o i f, Implikasi Itsbat Nikah Tehadap Status Perkawinan Dan Anak Dalam Kepastian Hukum...

pencatat nikah yang tidak

mencatat

dihubungkan

perkawinan,

kedudukannya

dengan

adminsitrasi negara ?

B. HASIL DAN PEMBAHASAN

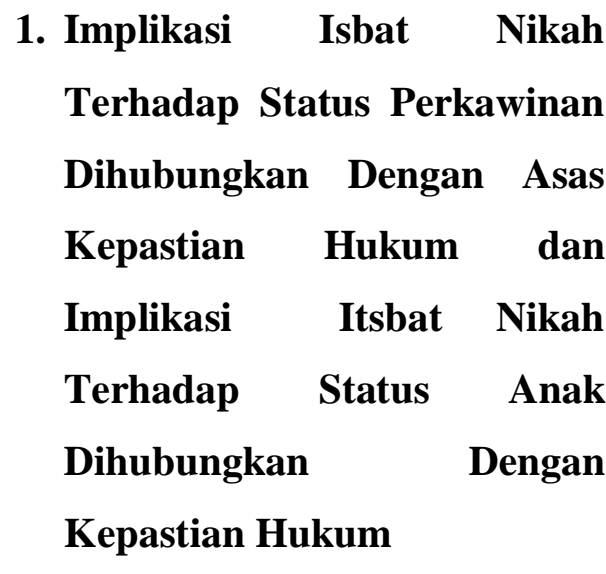

Pencatatan perkawinan

menurut aturan hukum di

Indonesia sangat urgen, sehingga meskipun perkawinan telah dilakukan dengan memenuhi syarat dan rukunya berdasarkan hukum Islam dianggap telah memenuhi ketentuan hukum materiil perkawinan, namun demikian, perkawinan tersebut belum memenuhi ketentuan hukum formil perkawinan karena belum dicatat oleh pegawai pencatat nikah.

\section{Dengan pencatatan}

perkawinan, yang dilakukan oleh
Pegawai Pencatat Nikah, hal ini penting bagi pemenuhan hak-hak suami/istri dan anak (terutama pemilikan terhadap harta waris, pengakuan status anak, dasar hukum kuat bagi istri jika ingin menggugat suami atau sebaliknya). Pencatatan berfungsi sebagai perlindungan bagi istri/suami dan anak-anaknya. Oleh karenanya penulis katakan bahwa pencatatan pernikahan mempunyai dampak positif sehingga pencatatan nikah sangatlah urgen.

Adapaun metode (manhaj) yang penulis pakai dalam pembahasan pencatatan perkawinan ini ada dua yaitu Qiyas dan Mashlahah al Mursalah dan Saduzari'ah .

Hukum harus mampu memberikan perlindungan terhadap semua pihak karena setiap orang memiliki kedudukan yang sama di hadapan hukum, sehingga perlindungan hukum yang merupakan gambaran dari bekerjanya fungsi hukum harus mampu mewujutkan tujuan-tujuan hukum yakni terjaminnya 
To i f, Implikasi Itsbat Nikah Tehadap Status Perkawinan Dan Anak Dalam Kepastian Hukum...

ketertiban, keadilan, kemanfaatan dan kepastian hukum.

Bentuk perlindungan hukum dalam upaya memperoleh kepastian hukum terhadap perkawinan yang tidak tercatat karena kesalahan pencatat dengan Isbat Nikah, dengan alasan diantaranya, sebagaimana yang tercantum dalam Kompilasi Hukum Islam Pasal 7 ayat (3) menjelaskan sebagai berikut:

a. Adanya perkawinan dalam rangka penyelesaian perceraian;

b. Hilangnya akta Naikah;

c. Adanya keraguan tentang sah atau tidaknya salah satu nsyarat perkawinan;

d. Adanya perkawinan yang terjadi sebelum berlakunya Undang-Undang Nomor 1 Tahun $1974 \quad$ tentang Perkawinan;

e. Perkawinan yang dilakukan oleh mereka yang tidak mempunyai halangan perkawinan menurut halangan perkawinan menurut UndangUndang Nomor 1 Tahun 1974 tentang Perkawinan.
Adapun alasan yang digunakan dasar mengajukan permohonan isbat nikah adalah sebagaimana tersebut diatas, sedangkan alasan permohonan Isbat Nikah yang tidak tercatat karena kesengajaan pencatat nikah tidak melakukan pencatatan, tidak tercantum dalam pasal-pasal tersebut, sehingga alasan tersebut memerlukan penafsiran lebih lanjut yang mampu mengakses terhadap kesalahan pencatat yang tidak mencatatkan perkawinan pasangan perkawinan dan sematamata kesalahan itu bukan kesalahan pasangan perkawinan, akan tetapi kesalahan itu tertumpu pada petugas pencatat perkawinan, yang dengan sengaja tidak mencatatkan perkawinan pasangan perkawinan, oleh karenanya pasangan perkawinan tidak bisa dipersalahkan dan justru pasangan perkawinan berhak mendapatkan perlindungan hukum atas kesewenang-wenangan pencatat nikah atas perkawinannya.

$$
\text { Pasal } 7 \text { ayat (3) huruf e }
$$
Kompilasi Hukum Islam, telah 
T o if, Implikasi Itsbat Nikah Tehadap Status Perkawinan Dan Anak Dalam Kepastian Hukum...

memberikan peluang kepada pasangan perkawinan yang telah melakukan perkawinan sesuai dengan Pasal 2 ayat (1) UndangUndang Nomor 1 Tahun 1974 tentang Perkawinan, yang tidak tercatat, yang mana isbat nikah bisa diajukan oleh mereka yang melakukan perkawinan tidak mempunyai halangan menurut Undang-Undang Nomor 1 Tahun 1974 tentang Perkawinan.

Meskipun pasal tersebut tidak secara jelas memberikan peluang untuk mengajukan isbat nikah bagi perkawinan yang tidak tercatat karena kesengajaan pegawai pencatat nikah tidak mencatatkan perkawinan pasangan suami istri, namun secara implisit masih terbuka bagi pasangan perkawinan yang tidak tercatat perkawinannya karena kesengajaan pencatat nikah untuk mengajukan Isbat Nikah.

Adapun Argumentasi penulis terhadap isbat nikah masih terbuka bagi perkawinan yang tidak tercatat karena kesengajaan pegawai pencatat nikah adalah: Mayoritas isbat nikah diajukan karena perkawinannya tidak tercatat, sehingga belum mempunyai kepastian hukum terhadap perkawinannya, Pemohon isbat nikah tidak mempunyai bukti perkawinan yang berupa Buku Kutipan Akta Nikah, Perkawinan yang dimohonkan itsabat nikah, perkawinanya telah dilaksanakan sesuai dengan Pasal 2 ayat (1), Mayoritas pasangan perkawinan yang tidak tercatat dan yang di ajukan di Pengadilan Agama Trenggalek mempunyai kesulitan di dalam pemenuhan terhadap hakhak keperdataannya.

Dari fakta yang terjadi baik Isbat Nikah yang diajukan karena alasan sebagaimana yang tercantum dalam Pasal 7 (3) huruf a, b, c, d, e dan Isbat Nikah diajukan karena kesengajaan pencatat nikah yang tidak mencatatkan perkawinan pasangan perkawinan, keduanya mempunyai fakta yang sama yaitu sama-sama tidak mempunyai Buku Kutipan Akta Nikah, sehingga keabsahan perkawinannya tidak bisa dibuktikan dengan Buku Kutipan Akta Nikah. Oleh karena 
To i f, Implikasi Itsbat Nikah Tehadap Status Perkawinan Dan Anak Dalam Kepastian Hukum...

kedua-duanya tidak memiliki Buku Kutipan Akta Nikah maka kedua bentuk perkawinan tersebut mempunyai hak untuk mengajukan Isbat Nikah sebagai bentuk perlindungan hukum yang harus diterima oleh pasangan perkawinan yang tidak mempunyai Buku Kutipan Akta Nikah, sehingga diperoleh kepastian hukum atas perkawinanya.

Asas-asas hukum Islam yang menjadi tumpuan atau landasan untuk melindungi kepentingan pribadi sesorang yang perkawinannya tidak dicatat karena kesengajaan pencatat nikah tidak mencatatkan perkawinanya, sebagian diantaranya adalah: 1) Asas kemaslahatan hidup, 2) Asas menolak madharat dan mengambil manfaat, 3) Asas menolak madharat dan mengambil manfaat,

4) Asas larangan merugikan diri sendiri dan orang lain, 5) Asas perlindungan hak, 6) Asas yang beriktikat baik harus dilindungi.

Adapun tujuan hukum pada hukum positif adalah, sematamata untuk mewujudkan keadilan yaitu apa yang adil dan apa yang tidak adil dan langsung dirasakan oleh masyarakat.

Pegawai pencatat nikah telah melakukan ketidak adilan terhadap pasangan suami istri, sehingga berimbas kepada ketidak pastian hukum adanya perkawinan dan kerugian terhadap kepentingan perdata pasangan suami istri, hal tersebut terjadi karena keadilan tidak terpenuhi, justru kedhaliman dan kesulitan yang dihadapi pasangan suami istri.

Disamping itu tujuan hukum adalah semata-mata untuk menciptakan kemanfaatan atau kebahagiaan yang bisa dirasakan oleh masyarakat (pasangan perkawinan). Tindakan pegawai pencatat nikah, telah bertentangan dengan tujuan hukum untuk menciptakan kemanfaatan, karena dengan tidak dicatatnya perkawinan, berakibat pasangan suami istri, tidak bisa mengambil kemanfaatan atas pencatatan perkawinan.

Adapun tujuan hukum yang selanjutnya adalah untuk memperoleh kepastian hukum berarti tidak dicatat dan tidak 
dimilikinya buku Kutipan Akta Nikah menyebabkan perkawinan pasangan suami istri tidak memiliki kepastian hukum, sehingga harus diberikan perlindungan hukum dalam upaya mendapatkan kepastian hukum.

Diantara unsur-unsur kepastian hukum itu adalah Dengan penetapan itsbat nikah telah terwujud adanya kejelasan norma sebagai dasar yang dijadikan pedoman bagi masyarakat/pasangan suami istri, dengan Itsbat Nikah diperoleh adanya ketegasan terhadap berlakunya hukum di dalam masyarakat, dengan Itsbat Nikah diperoleh adanya jaminan bahwa penetapan tersebut dapat dijalankan, itsbat nikah merupakan bentuk perlindungan terhadap tindakan sewenangwenang.

Tugas Negara dalam Islam adalah menjaga agama (Miraasatuddiin) dan mengatur urusan dunia (wasii'atuddunya), sebagaimana dikatakan oleh Al Mawardi dalam kitabnya $A l$ Ahkamu Shulthaniyah sebagai berikut: Imam (kepemimpinan) bertugas sebagai pengganti kenabian dalam melindungi Agama dan mengatur kemaslahan hidup (Imam Al Mawardi, 2015:9). Disebutkan pula di dalam Fiqhul Islamiyu Wa Adillatuhu adalah "tugas dan fungsi adDaulah al-Islamiyah adalah menjaga urusan dunia dan Agama (Wahbah Az-Zuhaili, 2011:460). Pemerintah mengurus rakyatnya sesuai dengan kemaslahatan (Departemen Agama Republik Indonesia, Tt:38).

Pegawai Pencatat Perkawinan, yang tidak mencatat perkawinan pasangan perkawinan yang dibawah pengawasannya, merupakan bentuk kedholimannya, hal ini sesuai dengan penjelasan yang terdapat di dalam kitab AlAhkmu Shulthaniyah, sebagai berikut: "akan tetapi jika berlebihanya itu sebagai wujud kedhaliman, yang demikian wajib ditolak dan ia wajib diberi sanksi atas sikap dhalimnya itu" (Imam Al Mawardi, 2015:370).

Pengaturan pencatatan
perkawinan dan keharusan


T o i f, Implikasi Itsbat Nikah Tehadap Status Perkawinan Dan Anak Dalam Kepastian Hukum...

penolakan jika terjadi ke sewenang-wenangan pegawai pencatat perkawinan, merupakan menyempurnakan konsep maslahat tingkatan al-Dharuriyah (primer) yang disebut dengan tingkatan al Hajiyah (sekunder). Sedangkan isbat nikah yang diajukan oleh pasangan perkawinan yang dengan sengaja tidak dicatat perkawinannya oleh petugas pencatat, adalah dalam rangka terpeliharannya lima tujuan hukum Islam yang disebut maqasid alsyari'ah.

Adapun implikasi isbat nikah terhadap status perkawinan dihubungkan dengan asas kepastian hukum adalah, perkawinan dari pasangan suami istri yang di itsbatkan menjadi sah, karena perkawinan tersebut telah memenuhi ketentuan Pasal 2 ayat (1) dan ayat (2) Undang-Undang Nomor 1 Tahun 1974 tentang Perkawinan dan telah memenuhi unsur-unsur kepastian hukum.

Implikasi lain yang terbentuk akibat perkawinan sah, diantaranya adalah :Timbulnya hak dan kewajiban antara suami istri, anak- anak yang lahir dari perkawinannya menjadi anak sah, Timbulnya hak dan kewajiban antara orang tua dengan anak, Timbulnya hak waris mewarisi antara orang tua dengan anak-anak yang dilahirkannya, orang tua lakilaki berhak dan berkewajiban menjadi wali nikah atas pernikahan anak perempuanya, orang tua berkewajiban menjadi wali dari anak-anaknya, terbentukanya harta bersama antara suami dan istri, timbulnya hak waris mewarisi antara suami dan istri.

Adapun implikasi itsbat nikah terhadap status anak adalah memberikan landasan kepastian terhadap status anak, karena dengan disahkannya perkawinan pasangan suami istri melalui itsbat nikah, secara tidak langsung telah memberikan landasan pengakuan terhadap anak-anak yang dilahirkan menjadai anak sah dari pasangan suami istri.

Dengan penetapan Itsbat Nikah pula secara hukum memberikan landasan kepastian terhadap hak-hak dan kewajiban orang tua kepada anak yang 
dilahirkan dengan segala akibat hukum yang timbul dari pernikahan yang sah, baik secara syariat maupun menurut hukum warga negara.

Dalam upaya memberikan kepastian hukum terhadap status anak yang lahir dari perkawinan yang tidak tercatat karena kelalaian dan kesengajaan petugas pencatat, maka upaya melakukan perlindungan hukum untuk memperoleh kepastian hukum terhadap staus anak yang telah lahir, yaitu dengan permohonan penetapan asal-usul anak ke Pengadilan Agama.

Asal usul anak merupakan dasar untuk menetapkan adanya hubungan nasab dengan ayah dan ibunya, demikian yang diyakini oleh fiqh suni, karena para ulama sepakat bahwa anak zina atau anak mula'anah dan anak syubhat hanya mempunyai hubungan nasab dengan ibu dan sudara ibunya (Pelmizar Dt. Batungkek Ameh, 2009:1).

Untuk menentukan dan menjaga asal-usul (nasab) seseorang, dalam pengertian, nasab seseorang hanya bisa dinisbahkan kepada kedua orang tuanya kalau ia dilahirkan dalam perkawinan yang sah (Amir Syarifuddin, 2002:199).

Dalam perspektif Hukum Islam Nasab anak terhadap ayah bisa terjadi karena tiga hal (Wahbah al Zuhaili, 1989:681), yaitu:

a. Melalui perkawinan yang sah;

b. Melalui perkawinan yang Fasid;

c. Melalui Hubungan senggama karena adanya subhah an nikah (nikah subhat).

Disamping itu menurut Undang-Undang Nomor 1 Tahun 1974 tentang Perkwinan, dalam Pasal 42 dijelaskan sebagai berikut: "Anak yang sah adalah anak yang dilahirkan dalam atau sebagai akibat perkawinan yang sah" (Zaenal Abidin, Tt).

Adapun dasar pemikiaran terhadap produk penetapan pengadilan Agama terhadap asal usl anak, sehingga penetapan asal usul anak mempunyai implikasi terhadap status anak dihubungkan dengan kepastian hukum. 
Pengadilan Agama adalah salah satu Pengadilan yang ada di negara Indonesia yang berdasarkan atas Pancasila, yang mana Pengadilan Agama mempunyai kedudukan yang seimbang dengan Pengadilan yang lain yang ada di negara Republik Indonesia. Oleh karenanya, berdasarkan paparan sebagaimana tersebut di atas, penetapan asal-usul anak mempunyai implikasi terhadap anak yang lahir dari perkawinan orang tauanya, yaitu mampu memberikan kepastian hukum terhadap keabsahan seorang anak yang lahir dari perkawinan orang tuanya menjadi anak sah.

Adapun tujuan hukum yang selanjutnya adalah untuk memperoleh kepastian hukum, berarti dengan penetapan asal-usul anak menyebabkan anak-anak yang dilahirkan dari pasangan suami istri telah memiliki kepastian hukum dan menjadi anak sah.

Dalam tata aturan hukum, dalam hal ini hukum perdata, sebagaimana yang telah disebutkan dalam Bab III, permohonan asal-usul anak adalah, salah satu bentuk perlindungan hukum yang digunakan untuk mendapatkan kepastian hukum, karena dengan permohonan asalusul anak terpenuhi unsur-unsur kepastian hukum. Diantara unsurunsur kepastian hukum dalam penetapan asal-usul anak adalah: Dengan penetapan asal-usul anak telah terwujud adanya kejelasan norma/aturan, sebagai dasar yang dijadikan pedoman bagi masyarakat/ pasangan suami istri, dengan penetapan asal-usul anak, diperoleh adanya ketegasan terhadap berlakunya hukum di dalam masyarakat, sehingga anakanak yang dilahirkan oleh pasangan suami istri mendapat ketegasan hukum, dengan penetapan asal-usul anak, diperoleh adanya jaminan bahwa penetapan tersebut dapat dijalankan, penetapan asal-usul anak, merupakan bentuk perlindungan terhadap tindakan sewenang-wenang, yang berarti anak-anak yang dilahirkan dapat memperoleh sesuatu yang diharapkan dalam keadaan 
tertentu yaitu mendapatkan kepastian hukum atas kedudukannya sebagai seorang anak.

Sejalan dengan Tugas

Negara dalam Islam adalah:

Menjaga Agama (Miraasatuddiin) dan mengatur urusan dunia (wasii'atuddunya), sebagaimana dikatakan oleh Al Mawardi dalam kitabnya Al Ahkamu Shultaniyah yang artinya sebagai berikut: Imam (kepemimpinan) bertugas sebagai pengganti kenabian dalam melindungi Agama dan mengatur kemaslahan hidup (Imam Al Mawardi, 2015:9).

Disebutkan pula di dalam Fiqhul Islamiyu Wa Adillatuhu adalah tugas dan fungsi ad-Daulah al-Islamiyah adalah menjaga urusan dunia dan Agama (Wahbah Az-Zuhaili, 2011:460). Dalam qoidul fighiyah yang artinya disebutkan: Pemerintah mengurus rakyatnya sesuai dengan kemaslahatan

(Departemen Agama Republik Indonesia, Tt:38).

Oleh karena Itsbat Nikah merupakan landasan kepastian hukum terhadap status keabsahan anak dan asal usul anak juga merupakan landasan kepastian hukum, untuk memperoleh status keabsahan anak. Akibat hukum terhadap orang tuanya dan terhadap dirinya, diantaranya adalah: Timbulnya hak dan Kewajiban antara orang tua dengan anak begitupun sebaliknya, timbulnya hak waris mewarisi antara anak dengan orang tuanya begitupun sebaliknya, terjadinya penghalang Nasabiyah dalam perkawinan, anak perempuan berhak mendapat wali nikah dari orang tua laki-laki dan sebaliknya orang tua laki-laki wajib menjadi wali nikah atas anak perempuanya, anak berhak mendapatkan perwalian dari orang tuanya.

\section{Pertanggung Jawaban}

Pegawai Pencatat Nikah

Dalam Kedudukannya

Sebagai Administrasi Negara dan Pertanggung Jawaban Pegawai Pencatat Nikah

Dalam Perspektif Hukum

Pidana Pelanggaran 
Pegawai pencatat Nikah yang diangkat oleh Kementerian Agama yang mempunyai hak untuk melakukan pengawasan atas nikah dan apa bila pegawai pencatat nikah tidak ada atau berhalangan maka pekerjaan itu dilakukan oleh orang yang ditunjuk sebagai wakilnya untuk melakukan pencatatan nikah, sehingga keabsahan suatu pernikahan yang telah memenuhi Pasal 2 ayat (1) dan ayat (2) Undang-Undang Nomor 1 Tahun 1974 tentang Perkawinan, juga ditentukan oleh pegawai pencatat nikah.

Disahkanya Undang-Undang Nomor 1 Tahun 1974 tentang Perkawinan, yang ditindalanjuti dengan Peraturan Pemerintah Nomor 9 Tahun 1975 dan juga ditindaklanjuti untuk lingkup yang terbatas Peraturan Pemerintah Nomor 10 Tahun 1983, tentang izin perkawinan dan Peceraian bagi Pegawai Negeri Sipil, di dalamnya memuat tentang pencatatan pernikahan, menjadikan pemikiran hukum yang bernuansa baru di negara
Indonesia, yang pemikiran hukum baru tersebut belum dibahas dalam kitab-kitab fiqh klasik maupun dalam kitab fiqh kontemporer, termasuk di dalamnya tentang sanksi hukum terhadap pegawai pencatat yang telah melanggar wewenang yang telah diberikan kepadanya.

$$
\text { Pasal } 2 \text { ayat (1) dan (3) }
$$

Peraturan Pemerintah Nomor 9 Tahun 1975 tentang Pelaksanaan Undang-Undang Nomor 1 Tahun 1974 tentang Perkawinan menyebutkan sebagai berikut (Departemen Agama Republik Indonesia, 2015:826):

(1) Pencatatan Perkawinan dari mereka yang melangsungkan perkawinannya menurut Agama Islam dilakukan oleh Pegawai Pencatat, sebagaimana dimaksud dalam Undang-Undang Nomor 32 Tahun $1954 \quad$ Tentang Pencatatan Nikah, Talak dan Rujuk.

(3) Dengan tidak mengurangi ketentuan-ketentuan yang khusus berlaku bagi tatacara pencatatan perkawinan 


$\begin{array}{lr}\begin{array}{l}\text { berdasarkan } \\ \text { peraturan } \\ \text { tatacara }\end{array} & \begin{array}{r}\text { berbagai } \\ \text { berlaku, }\end{array} \\ \text { perkawinan } & \begin{array}{r}\text { pencatatan } \\ \text { dilakukan, }\end{array} \\ \text { sebagaimana } & \text { ditentukan } \\ \text { dalam pasal 3 } & \text { sampai dengan } \\ \text { pasal 9 Peraturan Pemerintah } \\ \text { ini. }\end{array}$

Tatacara perkawinan, sebagaimana disebutkan di dalam Pasal 10 Peraturan Pemerintah Nomor 9 Tahun 1975 tersebut menyatakan (Departemen Agama Republik Indonesia, 2015:828):

(1) Perkawinan dilangsungkan setelah hari kesepuluh sejak Pengumuman kehendak perkawinan oleh Pegawai Pencatat, seperti yang dimaksud dalam Pasal 8 Peraturan Pemerintah ini.

(2) Tatacara perkawinan dilakukan menurut hukum masing- masing agamanya dan kepercayaannya itu.

(3) Dengan mengindahkan tatacara perkawinan menurut masing-masing hukum agamanya dan kepercayaannya itu, perkawinan dilaksanakan dihadapan Pegawai Pencatat dan di hadiri oleh dua orang saksi.

Di dalam Pasal 11 ayat (1), ( 2) dan (3) Peraturan Pemerintah Republik Indonesia Nomor 9 Tahun 1975 ini, menyebutkan (Departemen Agama Republik Indonesia, 2015:828):

(1) Sesaat sesudah dilangsungkan perkawinan sesuai dengan ketentuan-ketentuan Pasal 10 Peraturan Pemerintah ini, kedua mempelai menandatangani akta perkawinan yang telah disiapkan oleh Pegawai Pencatat berdasarkan ketentuan yang berlaku.

(2) Akta Perkawinan yang telah ditandatangani oleh mempelai itu, selanjutnya ditandatangani pula oleh kedua saksi dan Pegawai Pencatat yang menghadiri perkawinan dan bagi yang melangsungkan perkawinan menurut Agama Islam, ditandatangani pula oleh wali nikah atau yang mewakilinya. 
To i f, Implikasi Itsbat Nikah Tehadap Status Perkawinan Dan Anak Dalam Kepastian Hukum...

(3) Dengan menandatangani akta perkawinan, maka perkawinan telah tercatat secara resmi.

Dari ketentuan pasal-pasal sebagaimana tersebut diatas, pegawai penatat nikah tidak mencatat perkawinan pasangan suami istri dan tidak memberikan buku kutipan akta nikah, berarti pegawai pencatat nikah telah menyimpang dari kewenangan yang diberikan oleh undangundang, sekaligus menyimpangt dari peraturan pelaksana dari undang-undang, oleh karena itu pegawai pencatat nikah harus dikenai sanksi hukum.

Sanksi hukum yang diberikan kepada pegawai pencatat nikah yang tidak mencatat perkawinan pasangan perkawinan, karena kesengajaannya, patut diberikan hukuman, karena tindakan yang dilakukan telah menyebabkan perkawinan pasangan suami istri tidak mendapatkan perlindungan hukum, urusan perbuatan hukum lain menjadi sulit, perkawinan yang dilakukan pasangan suami istri tidak mempunyai legalitas formal di depan hukum, karena dengan pencatatan pernikahan dianggap legal dan dengan dicatat pula perkawinan terjamin keamanannya karena akan terhindar dari pemalsuan ataupun kecurangan dari salah satu pihak suami atau istri.

Untuk memberikan sanksi kepada pegawai pencatat nikah atau orang yang telah mendapatkan mandat untuk itu (pencatat), harus dilihat dari segi kewenangnya, sekiranya tindakanya itu telah melampaui wewenangnya (melampaui kewenangnanya) sehingga bertindak sewenangwenang maka patut diberikan sanksi.

Dibuatnya Undang-Undang Administrasi Pemerintahan merupakan upaya untuk menciptakan kepastian hukum kepada masyarakat dan badan/pejabat pemerintah. Keputusan yang dibuat oleh pejabat pemerintahan pun dipastikan sesuai dengan kaidah hukum dan metanorma dalam prinsip-prinsip jalannya pemerintahan. 
To i f, Implikasi Itsbat Nikah Tehadap Status Perkawinan Dan Anak Dalam Kepastian Hukum...

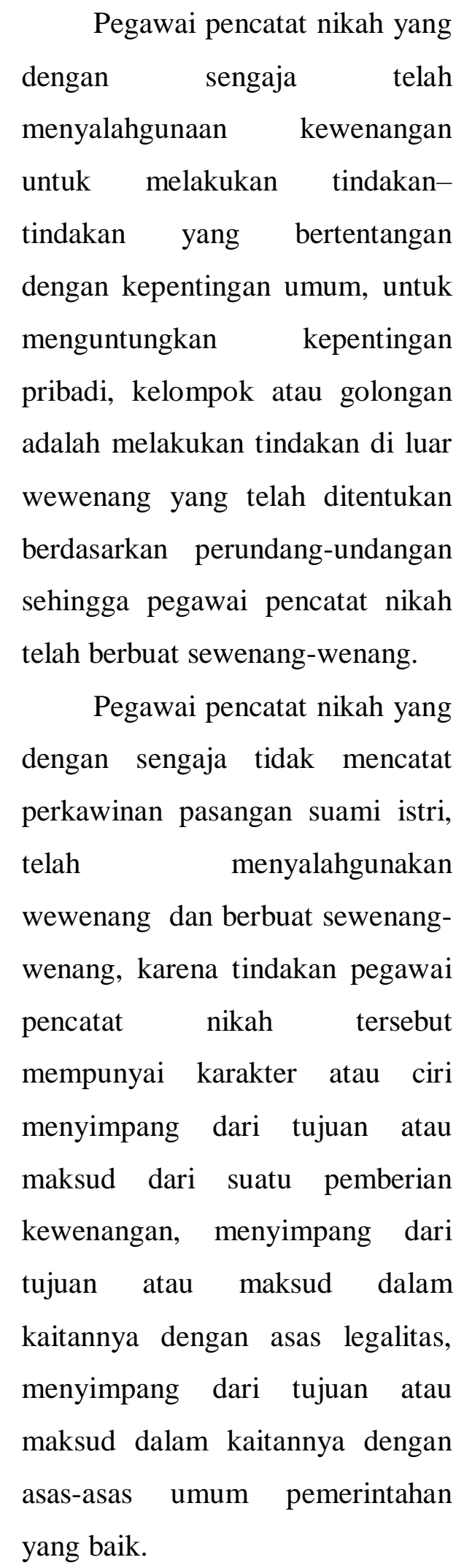

Sanksi

Administratif

sebagaimana yang disebutkan di dalam Pasal 80 Undang-Undang Nomor 30 Tahun 2014 tentang Administrasi Pemerintahan adalah dikenai sanksi administratif ringan, dikenai sanksi administratif sedang, dikenai sanksi administratif berat (Pejabat Pemerintahan yang melanggar ketentuan sebagaimana dimaksud pada ayat (1) atau ayat (2) yang menimbulkan kerugian pada keuangan negara, perekonomian nasional, dan/atau merusak lingkungan hidup dikenai sanksi administratif berat).

Apa yang dilakukan oleh pencatat nikah bertentangan dengan qoidah fiqhiyah yang artinya Pemerintah mengurus rakyatnya sesuai dengan kemaslahatan. Demikan pula mengenai pegawai pencatat nikah, yang tidak mencatat perkawinan pasangan suami istri yang berada dibawah pengawasannya merupakan bentuk kedholimannya, hal ini sesuai dengan penjelasan yang terdapat di dalam kitab Al Ahkamu Shulthaniyah, yang 
To i f, Implikasi Itsbat Nikah Tehadap Status Perkawinan Dan Anak Dalam Kepastian Hukum...

artinya sebagai berikut : akan tetapi jika berlebihanya itu sebagai wujud kedhaliman, yang demikian wajib ditolak dan ia wajib diberi sanksi atas sikap dhalimnya itu (Imam Al Mawardi, 2015:370).

Pegawai penatat nikah dalam hal ini sebagai perpanjangan dari pemerintah, sebagai anutan yang harus ditaati sebagai ulil amri, akan tetapi justru sebagai administrasi negara ( pemerintah ) tidak memposisikan sebagai ulil amri dan justru menyimpang dari aturan kenegaraan yang seharausnya menjaga miroosatuddiin dan wasiiatuddunya. Oleh karenanya pegawai pencatat nikah tersebut harus diberikan hukuman berat dengan pemecatan.

Adapun perbuatan pegawai pencatat nikah yang dengan sengaja tidak mencatat perkawinan pasangan suami istri yang berada di hadapan dan bawah pengawasanya, yang karena pegawai pencatat nikah tersebut sebagai pegawai yang ditunjuk untuk melakukan pencatatan akan tetapi pencatatan tidak dilakukan dan tidak memberikan kutipan akta nikah kepada pasangan suami istri yang telah melakukan perkawinan dihadapanya dan di bawah pengawasanya, sehingga perbuatan pegawai pencatat nikah tersebut dianggap sebagai kejahatan yang mengarah kepada kriminalisasi dan dapat dipidana.

Pada realitanya sesuai dengan Pasal 13 ayat (1) dan ayat (2), Peraturan Pemerintah. Nomor 9 Tahun 1975 tentang Pelaksanaan Undang-Undang Nomor 1 Tahun 1974 tentang Perkawinan, tindakan pegawai pencatat nikah tersebut dianggap telah melakukan tindak pidana pelanggaran.

Adapun ancaman tindak pidana pelanggaran, tidak ada yang diancam dengan pidana penjara, akan tetapi berupa pidana kurungan/denda.

Pegawai pencatat nikah telah melakukan pelanggaran terhadap Pasal 6, 7, 8, 9, 10 ayat (1), (11), (13), (44) Peraturan Pemerintah ini dihukum dengan hukuman kurungan selama-lamanya 3 (tiga) bulan atau denda setinggitingginya Rp. 7.500;- (tujuh ribu 
lima ratus rupiah) dan tindak pidana yang dimaksud dalam ayat (1) diatas merupakan pelanggaran.

\section{PENUTUP}

\section{Simpulan}

a. Implikasi Itsbat Nikah terhadap perkawinan dihubungkan dengan asas kepastian hukum adalah dengan adanya itsbat nikah, perkawinan yang terlaksana sebelumnya menjadi sah demikian pula terhadap anak anak yang dilahirkan dan memiliki kepastian hukum karena itsbat nikah tersebut telah memenuhi unsur-unsur kepastian hukum.

b. Pertanggungjawaban pegawai pencatat nikah yang dengan sengaja tidak mencatat perkawinan pasangan suami istri yang dilakukan dihadapan dan dibawah pengawasannya, dihubungkan dengan kedudukannya sebagai administrasi negara adalah pejabat administrasi negara tersebut harus mendapatkan konsekwensi hukum yang setimpal dengan perbuatanya yaitu dihukum dengan pemecatan. Perbuatan pegawai pencatat nikah yang dengan sengaja tidak mencatat dan tidak memberikan buku kutipan akta nikah kepada pasangan suami istri, dikategorikan kepada tindak pidana pelanggaran sehingga dihukum dengan hukuman kurungan selama-lamanya 3 (tiga) bulan atau denda setinggi-tingginya Rp.7.500;(tujuh ribu lima ratus rupiah).

\section{Saran}

a. Bagi Pasangan perkawinan yang telah melakukan perkawinan dihadapan dan dibawah pengawasan pegawai pencatat nikah dan perkawinannya tidak dicatat oleh Pegawai Pencatat Nikah dan anaknya, segera mengajukan isbat nikah dan terhadap anak yang dilahirkan sekiranya tidak mengajukan itsbat nikah 
dengan mengajukan permohonan asal usul anak ke Pengadilan Agama.

b. Sanksi pelanggaran pencatatan perkawinan yang dilakukan oleh pegawai pencatat nikah, sangat ringan dan tidak relevan dengan akibat hukum yang timbul dan harus diterima oleh pasangan suami istri, oleh karenanya sanksi yang sangat ringan yang tercantum dalam Peraturan Pemerintah Nomor 9 Tahun 1975 tantang Pelaksanaan Undang-Undang Nomor 1 Tahun 1974 tentang Perkawinan, harus segera di revisi dan diganti dengan sangsi pidana kejahatan yang hukumanya dengan penjara dan dapat pula dituntut dengan perbuatan melawan hukum (perdata, pidana dan pidana korupsi).

\section{DAFTAR PUSTAKA}

Abdul gani Abdullah, Pengantar Kompilasi Hukum Islam Dalam Tata Hukum
Indonesia, Gema Insani Press, Jakarta, 1994.

Amir Syarifuddin, Meretas Kebekuan Ijtihad-Isu-isu Penting Hukum Islam Kontemporer di Indonesia, Ciputat Press, Jakarta, 2002.

Andi Syamsu Alam H., dan M. Fauzan H., Hukum Pengangkatan Anak Perspektif Islam, Pena Media, Jakarta, 2008.

Departemen Agama Republik Indonesia, Himpunan Peraturan PerundangUndangan Dilingkungan Peradilan Agama, Direktorat Jendral Badan Peradilan Agama, Jakarta, 2015.

, Himpunan Nash Dan Hujjah Syari'ah, Putusan Penetapan Pengadilan Agama, Proyek Pembinaan Badan Peradilan Agama Departemen Agama, Tt.

Imam Al Mawardi, Tarjamah Al Ahkam ash- shulthaniyah oleh Khalifurrahman Fath dan Fatkhurahman, Qisthi Press, Jakarta, 2015.

Pelmizar Dt. Batungkek Ameh, Tes DNA Darah Sebagai Alat Bukti Penetapan Asal Usul Nak Di Pengadilan Agama, dikutip dari http://www.ptapadang.go. 
id/data/artikel, pada tanggal, 26 Mei 2009.

Wahbah al Zuhaili, Fiqhul l Islami wa Adillatuhu, Jilid Ke-3, Cetakan Ke-3, Darul Fikri, Damaskus, 1989.

Wahbah Az-Zuhaili, Fiqh Islam Wa Adilatuhu, Penerjemah Abdul Hayyie al-Kattani, dkk (penyunting Budi Permadi, Cetakan Ke-1, Jilid Ke-8), Gema Insani, Jakarta, 2011.

\begin{tabular}{|c|c|}
\hline Zaenal & $\begin{array}{lr}\quad \text { Abidin, } & \text { Kumpulan } \\
\text { Peraturan } & \text { Perundang- } \\
\text { undangan } & \text { Dalam } \\
\text { Lingkungan } & \text { Peradilan }\end{array}$ \\
\hline & $\begin{array}{l}\text { Agama, Cetakan Ke-2, } \\
\text { Yayasan Al Hikmah, } \\
\text { Jakarta, Tt. }\end{array}$ \\
\hline
\end{tabular}

